\title{
Erratum to: Negotiating Childhoods - Applying a Moral Filter to Children's Everyday Lives
}

\author{
Sam Frankel
}

(C) The Editor(s) (if applicable) and The Author(s) 2018

S. Frankel, Negotiating Childhoods, Studies in Childhood and Youth, DOI 10.1057/978-1-137-32349-1

DOI 10.1057/978-1-137-32349-1

The original version of this book was revised. The affiliation of the author has been corrected to:

Sam Frankel

EquippingKids, Church Stretton

Shropshire, UK

The updated original online version for this book can be found at DOI 10.1057/978-1-137-32349-1

(C) The Editor(s) (if applicable) and The Author(s) 2018

S. Frankel, Negotiating Childhoods, Studies in Childhood and Youth, DOI 10.1057/978-1-137-32349-1_10 